\title{
The Learning Perspective for the Course of Instrumentation Technique through Project Based Learning
}

\author{
Islavatu Srikanth ${ }^{1}$, VRSV Bharath Pulavarthi ${ }^{2}$, Rajanikant A. Metri ${ }^{3}$, C.L.Bhattar ${ }^{4}$ \\ 1,2,3,4 Electrical Engineering Department, Rajarambapu Institute of Technology, Sakharale, Sangli-DT,MH, INDIA. \\ $\underline{1}$ srikanth.islavatu@ ritindia.edu,${ }^{2}$ bharath.pulavarthi@ ritindia.edu,${ }^{3}$ rajanikant.metri@ ritindia.edu, \\ chandrakant.bhattar@ ritindia.edu
}

\begin{abstract}
:
Now-a-days, instrumentation system configuration plays a vital role in the industrial process and manufacturing units. To know more details about the instrumentation system and learn about the basic ideas related system configuration and how to embed the system in real time applications and make use of programming languages. The project-based learning technique use to enhance knowledge of programming skills and implementation of the problem. This paper describes an intrusion to enhance students learning by adding the skill-oriented projects in instrumentation course to improve the knowledge about the current trends in instrumentation. This paper discusses the process of improving student performance by implementing PBL technique and the validated through comparing course attainment of two cases. i.e. with and without PBL. Also describes the assessment criteria to evaluate the student projects as per the rubrics. The results show that the implementation of the PBL improved higher-order cognitive skills, self-learning, teamwork, communication skills and involvement of the students to impart both technical content as well as generic professional skills.
\end{abstract}

Keywords: Project Based Learning, Course Outcomes, PBL, Assessment, Rubrics, Program outcomes.

\section{Introduction:}

The role of instrumentation system plays a vital role in multi-disciplinary fields like processes, manufacturing and agricultural industries. To prepare the job ready graduates it is required to focus on practical based curricula rather than more theoretical based content of instrumentation systems. It is also the responsibility of the curriculum designers to keep equilibrium between basics principles and advances of the current issues. However, Course teacher can motivate students through student centred delivery methods and assessment techniques. In a multi-disciplinary education context, project-based learning (PBL) [1] appears as one of the most interesting instructional strategies. The PBL technique tries to engage the students in real world tasks to enhance learning [2]. Students, typically organized in groups, face open multidisciplinary projects with the instructor playing the role of facilitator or coach. Every team design and implements a whole system with more than one possible approach, in an environment designed to simulate professional situations in which the students have to work with different kinds of knowledge. This practical scenario helps the students to understand the basis of electronics and its relevance as the basis for other disciplines. PBL is a student-centred strategy that fosters student initiative and focuses the student on real-world, open ended projects that can increase the motivation for most of them [3]. In this paper, using PBL technique students have the interest to do multi-disciplinary projects and the assessment of PBL using rubrics was discussed. Also, attainment of program outcomes for the course of Instrumentation technique's (Course code- EE3061) is improved though PBL.

\section{Methodology and Implementation:}

Instrumentation Techniques (EE3061) is three- credit theory course in the curriculum for third year B.Tech. electrical engineering under -graduate program. A course mini project is one learning opportunity to develop students in various aspects such as theoretical as well as practical aspects like understanding the concepts, problem selection, formulation, identification objectives, design and implementation [2]. This course is designed to cover the theory part to learn the basics of instrumentation system. This proposed work deals with designing assessment methods and development of rubrics and effective implementation of attainment techniques of course outcomes [2].

The structure of the course - instrumentation Techniques (EE3061) has Teaching Scheme (L-3, C- 3) and evaluation scheme (ISE-20, UT- 30M \& ESE - $50 \mathrm{M}$ ).

The program outcomes (POs) of Electrical Engineering undergraduate programme are given below

1. Apply knowledge of mathematics, science, and electrical engineering.

2. Design and conduct experiments, as well as to analyse and interpret data.

3. Design a system, components or process to meet desired needs within realistic constraints such as 
economic, environmental, social, political, ethical, health and safety, manufacturability and sustainability.

4. Function on multidisciplinary teams.

5. Identify, formulate, and solve electrical engineering problems.

6. Demonstrate professional and ethical responsibility.

7. Communicate effectively at work.

8. Understand the impact of electrical engineering solutions in global, economic, environmental, and societal context.

9. Engage in life-long learning.

10. Use the techniques, skills, and modern engineering tools necessary for engineering practice.

11. Apply the knowledge to evaluate contemporary issues or problems.

12. Participate and succeed in competitive exams.

The course outcomes (COs) are given below:

Course: Instrumentation Techniques, Course Code: EE3061

CO1: Describe basic concepts of instrumentation and characteristics of instruments.

CO2: Explain selection factors and application of transducers and sensors.

CO3: Discuss different types of signal conditioning devices.

CO4: Explain different data conversion techniques and digital instruments.

CO5: Describe different type of industrial process controllers.

The contribution of COs to POs mapping is depicted in the following Table. 1 .

Table 1: Correlation between POs and COs

\begin{tabular}{|c|c|c|c|c|c|c|c|c|c|c|c|c|}
\hline $\mathbf{C O s} / \mathbf{P O s}$ & $\mathbf{a}$ & $\mathbf{b}$ & $\mathbf{c}$ & $\mathbf{d}$ & $\mathbf{e}$ & $\mathbf{f}$ & $\mathbf{g}$ & $\mathbf{h}$ & $\mathbf{i}$ & $\mathbf{j}$ & $\mathbf{k}$ & $\mathbf{~}$ \\
\hline $\mathrm{CO} 1$ & 3 & & & & & & & & & & & 3 \\
\hline $\mathrm{CO} 2$ & 3 & & & 3 & & & & & & & & 3 \\
\hline $\mathrm{CO} 3$ & 3 & & & 3 & & & & & & & & \\
\hline $\mathrm{CO} 4$ & 3 & & & 3 & & & & & & & & 3 \\
\hline $\mathrm{CO} 5$ & 3 & & & 3 & & & & & & & & 3 \\
\hline
\end{tabular}

The delivery of the course has done in two ways that is one way is class room teaching and other is utilizing the tutorial hours to focus on experiments related the course and improve the skills of the students.

\section{Case study and Discussion:}

Case 1: Without Project Based Learning

This course was delivered by the instructor via ICT techniques like Moodle, animations, PPT by involving various assessment techniques like presentations, one to one interaction and Q\&A session. However, this seems more like a conventional manner as no hands on experience based assessment activities were included for student assessment and course delivery because of limitations of time due to not availability of laboratory sessions for the corresponding theory course. Hence the previous year course outcomes results obtained by the same course presented in Figure 1.

The course outcomes graph shown in Fig. 1

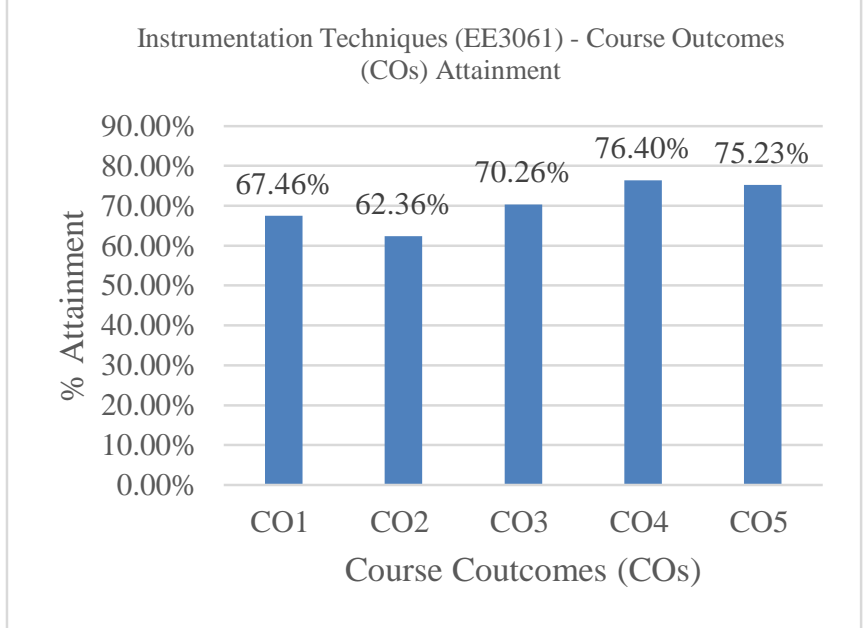

Figure 1. Attainment of course outcomes of Course EE3061 for AY 2017-18

\section{Case 2: With Project base learning}

To create the interest about subject among the students. This project-based learning is very much useful technique and this technique is implemented as an ISE component of the course. The weightage was given $20 \%$ out of $100 \%$. As a part of teaching learning activity, various case studies of real time applications were provided as assignments for better understanding. Students are expected to prepare the summary as a part of case studies and submission of technical report with in stipulated time. In other case, students are expected to identify, analyse, solve, design and implement a prototype based on real time applications. The role of the instructor is to mentor students and guide them to develop the prototype through continuous assessment. [2]

This course was assessed through In-Semester Evaluation (ISE), Unit Test (UT) and End Semester Evaluation (ESE) for maximum 100 marks. ISE and ESE are assigned 50 marks each. In ESE and UT Examinations student performance is evaluated through written test. The evaluation of ISE is included as an activity based to impart the skills and knowledge of students. The proposed work deals with the designing of assessment methods and development of rubrics and effective implementation of methods for the assessment of course learning outcomes.

The evaluation of ISE component is included two modes of evaluation schemes one is objective based (QUIZ) and other is activity based which includes the project-based learning (PBL). The assessment rubric sheet is shown in table 2.The likeminded students have become groups with group size 3-5 with at-least one boy and one girl. 
Table 2: Course mini project rubrics

\begin{tabular}{|c|c|c|c|c|}
\hline $\begin{array}{l}\text { Sr. } \\
\text { No: }\end{array}$ & Rubric & Need improvements (1-4) & Meet expectations (5-7) & Exceeds expectation (8-9) \\
\hline 1. & $\begin{array}{l}\text { Problem identification } \\
\text { Literature survey / Gather } \\
\text { information from multiple } \\
\text { sources } \\
\text { Formulate solution/ } \\
\text { Problem Description }\end{array}$ & $\begin{array}{l}\text { Needs to identify a problem } \\
\text { statement and/or related contextual } \\
\text { factors. } \\
\text { Uses limited information, based on } \\
\text { common knowledge and opinion. }\end{array}$ & $\begin{array}{l}\text { Constructs adequately detailed } \\
\text { problem statement with evidence of } \\
\text { contextual factors. } \\
\begin{array}{l}\text { Identifies } \\
\text { solution/position, } \\
\text { between points. }\end{array}\end{array}$ & $\begin{array}{l}\text { Constructs a clear and insightful } \\
\text { problem statement with evidence of all } \\
\text { relevant contextual factors. } \\
\text { Identifies appropriate solution/position } \\
\text { with sharp distinction between points, } \\
\text { coherent perspectives including } \\
\text { strengths and limitations. }\end{array}$ \\
\hline 2. & Innovative \& Usefulness & $\begin{array}{l}\text { Unable to provide/ describe } \\
\text { something new }\end{array}$ & $\begin{array}{l}\text { The solution described was useful } \\
\text { with the evidence but not innovative }\end{array}$ & $\begin{array}{l}\text { The solution is innovative and } \\
\text { usefulness was described clearly }\end{array}$ \\
\hline 3. & $\begin{array}{l}\text { Design of the project is } \\
\text { effective \& professional } \\
\text { Use of appropriate tools } \\
\text { and techniques for project } \\
\text { design }\end{array}$ & $\begin{array}{l}\text { Poor design and no design } \\
\text { techniques used. Basic concepts } \\
\text { used correctly Lack self-study, } \\
\text { but apply previously taught } \\
\text { technique on a satisfactory level } \\
\text { Relevant tools were not used }\end{array}$ & $\begin{array}{l}\text { Good design and design techniques } \\
\text { used Self-study of new concepts } \\
\text { /technique, with Good understanding } \\
\text { Minor innovative work } \\
\text { Tools were used and could design that } \\
\text { meets the requirements }\end{array}$ & $\begin{array}{l}\text { Good design with modular approach } \\
\text { and design techniques used. New } \\
\text { concepts used frequently Self-study of } \\
\text { new technique and solve technical } \\
\text { difficulties; } \\
\text { Tools were used to most and clear } \\
\text { design was done that describes the } \\
\text { system in detail }\end{array}$ \\
\hline 4. & $\begin{array}{l}\text { Testing of the project and } \\
\text { use of appropriate } \\
\text { tools/techniques } \\
\text { Quality of results }\end{array}$ & $\begin{array}{l}\text { No tools were used } \\
\text { Poor }\end{array}$ & $\begin{array}{l}\text { Tools were used and could test the } \\
\text { modules with appropriate explanation } \\
\text { for the faults } \\
\text { Appropriate to the expected outcomes }\end{array}$ & $\begin{array}{l}\text { Tools were used to most and system } \\
\text { was deployed correctly with an idea of } \\
\text { what fault caused the error } \\
\text { Perfectly matching the requirements }\end{array}$ \\
\hline 5. & $\begin{array}{l}\text { Organization of content } \\
\text { and readability in the } \\
\text { report on his/her module }\end{array}$ & $\begin{array}{l}\text { Poorly organized; no logical } \\
\text { progression; beginning and ending } \\
\text { are vague. Unable to find specific } \\
\text { details }\end{array}$ & $\begin{array}{l}\text { Organized; points are somewhat } \\
\text { jumpy; sense of beginning and } \\
\text { ending. Some details are non- } \\
\text { supporting to the subject }\end{array}$ & $\begin{array}{l}\text { Good organization; points are logically } \\
\text { ordered; sharp sense of beginning and } \\
\text { end. Supporting details specific to } \\
\text { subject }\end{array}$ \\
\hline
\end{tabular}

The results of COs attainment [3] based on Project based learning

The graph shown in figure 2. the clear result of the course outcomes

Instrumentation Techniques (EE3061) - Corse Outcomes (COs) Attainment

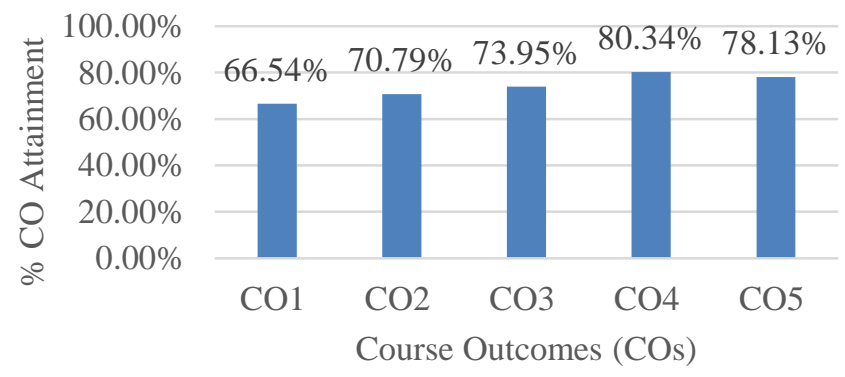

Figure 2: Attainment of Course Outcomes of course EE3061 for AY 2018-19

\section{Case III: $\mathrm{CO}$ - PO Mapping Contribution:}

With the help of project-based learning, students are more interested to participate and do the activity related to this. Also, students can improve the both inter personnel and intra personnel skills from this activity. By this activity, course outcomes of the course relatively improved, even the contribution of course outcomes with the programme outcomes greatly improved. The mapping of $\mathrm{CO}-\mathrm{PO}$ sharing with and without PBL is given below.
Without Considering the Course Mini Project (PBL):

Table 3: CO-PO mapping Contribution without PBL

\begin{tabular}{|c|c|c|c|c|c|c|c|c|c|c|c|c|c|c|}
\hline \multirow{2}{*}{$\begin{array}{l}\text { Sr. } \\
\text { No }\end{array}$} & \multirow{2}{*}{$\begin{array}{l}\text { Cour } \\
\text { se } \\
\text { Outc } \\
\text { omes }\end{array}$} & \multirow{2}{*}{$\begin{array}{l}\% \\
\text { CO } \\
\text { weigh } \\
\text { tage }\end{array}$} & \multicolumn{12}{|c|}{ Program Outcomes } \\
\hline & & & $\mathbf{a}$ & b & c & d & $\mathbf{e}$ & f & $\mathbf{g}$ & h & $\mathbf{i}$ & $\mathbf{j}$ & $\mathbf{k}$ & I \\
\hline 1 & $\mathrm{CO} 1$ & 5 & 3 & & & & & & & & & & & 3 \\
\hline 2 & $\mathrm{CO} 2$ & 10 & 3 & & & 3 & & & & & & & & 3 \\
\hline 3 & $\mathrm{CO} 3$ & 10 & 3 & & & 3 & & & & & & & & \\
\hline 4 & $\mathrm{CO} 4$ & 15 & 3 & & & 3 & & & & & & & & 3 \\
\hline 5 & $\mathrm{CO5}$ & 10 & 3 & & & 3 & & & & & & & & 3 \\
\hline
\end{tabular}

With Considering the Course Mini Project (PBL):

Table 4: CO-PO mapping Contribution with PBL

\begin{tabular}{|c|c|c|c|c|c|c|c|c|c|c|c|c|c|c|}
\hline \multirow{2}{*}{$\begin{array}{l}\text { Sr. } \\
\text { No }\end{array}$} & \multirow{2}{*}{$\begin{array}{l}\text { Cour } \\
\text { se } \\
\text { Outc } \\
\text { omes }\end{array}$} & \multirow{2}{*}{$\begin{array}{l}\% \\
\text { CO } \\
\text { weigh } \\
\text { tage }\end{array}$} & \multicolumn{12}{|c|}{ Program Outcomes } \\
\hline & & & $\mathbf{a}$ & $\mathbf{b}$ & c & d & $\mathbf{e}$ & $\mathbf{f}$ & $\mathbf{g}$ & $\mathbf{h}$ & $\mathbf{i}$ & $\mathbf{j}$ & $\mathbf{k}$ & l \\
\hline 1 & $\mathrm{CO} 1$ & 5 & 3 & & & & & & & & & & & 3 \\
\hline 2 & $\mathrm{CO} 2$ & 10 & 3 & 1 & & 3 & & & 1 & & & 3 & & 3 \\
\hline 3 & $\mathrm{CO} 3$ & 10 & 3 & 1 & & 3 & & & 3 & & & 3 & & \\
\hline 4 & $\mathrm{CO} 4$ & 15 & 3 & 1 & & 3 & & & 3 & & & 3 & & 3 \\
\hline 5 & $\mathrm{CO5}$ & 10 & 3 & & & 3 & & & & & & & & 3 \\
\hline
\end{tabular}

From the above table, the Course outcomes (Cos) are addressed more with Program outcomes with the implementation of project-based learning. 


\section{Result and discussions:}

The program outcomes of course without implementation of Project based learning (PBL) are given Table 5 and Figure.3

Table 5: Attainment of Program Outcomes (AY 2017-18)

\begin{tabular}{|l|l|}
\hline Program Outcomes & \% Attainment \\
\hline PO1 & 70.34 \\
\hline PO4 & 71.06 \\
\hline PO12 & 70.36 \\
\hline
\end{tabular}

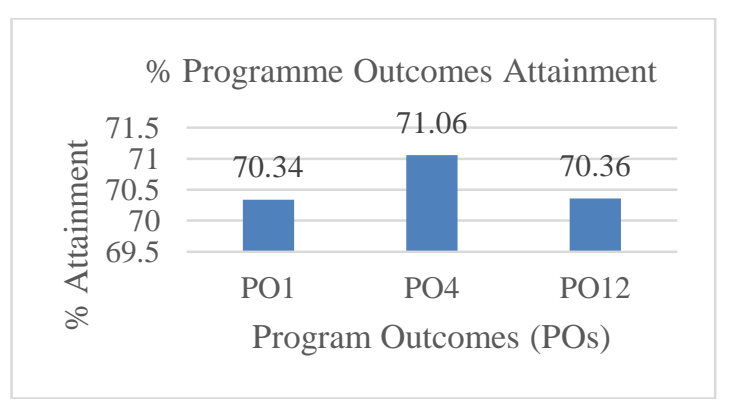

Figure 3: Contribution of Course EE3061 in PO Attainment (AY 2017-18)

By the implementation of project-based learning (PBL) the program outcomes are greatly improved. The results of Program outcomes (POs) are given in table 6 and shown in figure 4.

Table 6: Attainment of Program Outcomes (AY 2018-19)

\begin{tabular}{|l|l|}
\hline Program Outcomes & \% Attainment \\
\hline PO1 & 73.95 \\
\hline PO2 & 75.03 \\
\hline PO4 & 75.80 \\
\hline PO7 & 75.03 \\
\hline PO10 & 75.03 \\
\hline PO12 & 73.95 \\
\hline
\end{tabular}

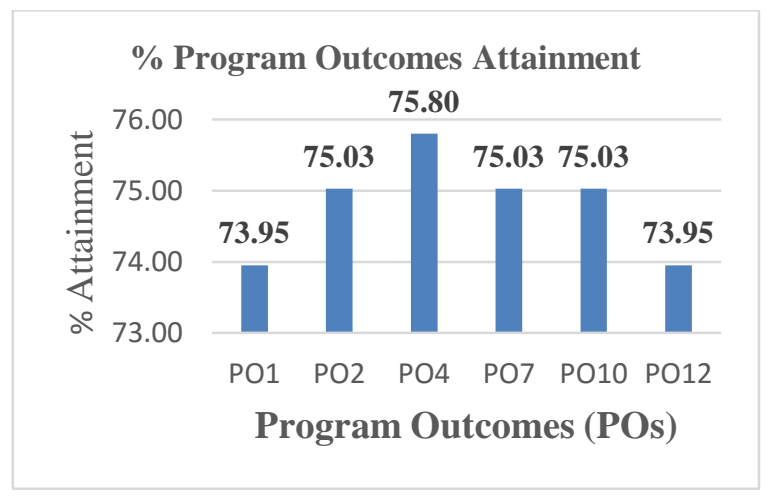

Figure 4: Contribution of Course EE3061 in PO Attainment (AY 2018-19)

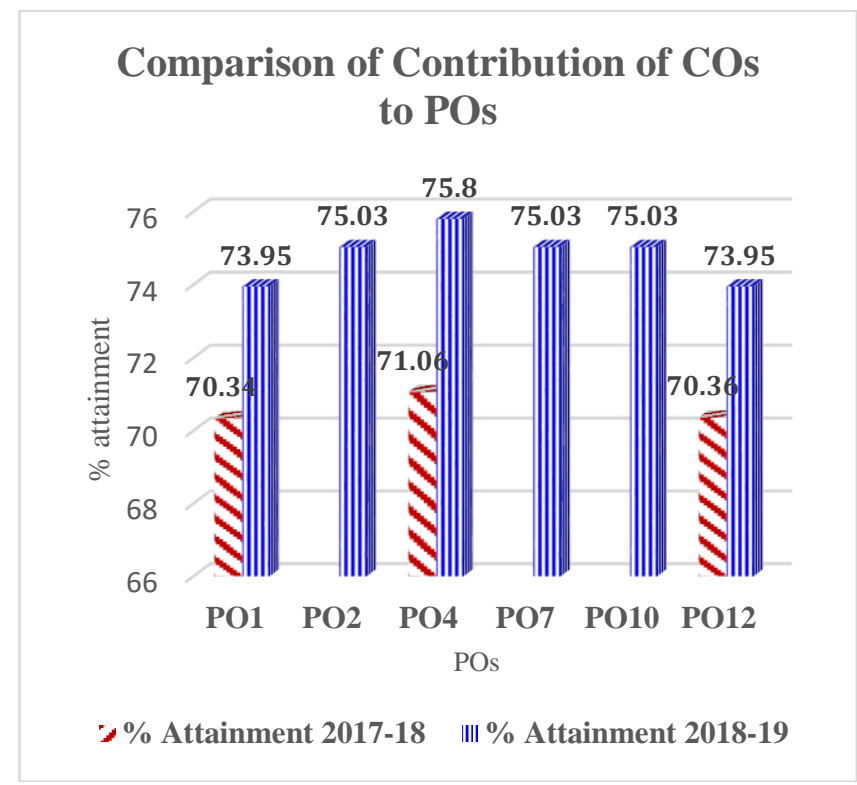

Figure 5: Comparison of Contribution of EE3061 COs to POs Attainment

Figure 5 shows the comparison of contribution from instrumentation course to the program outcomes for two consecutive academic years.

\section{Evaluations and student Feedback of Project based learning activity:}

The student's Evaluations and feedback on project-based learning is shown in figure 6 .

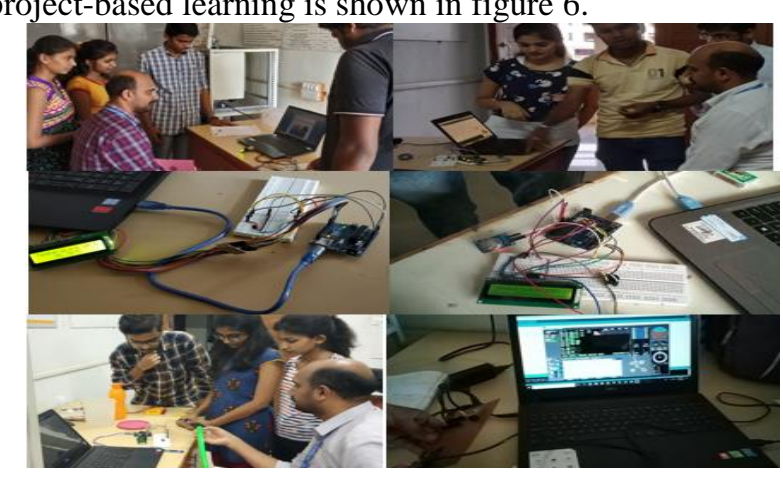

Figure 6: Evaluations of the Course mini Projects 


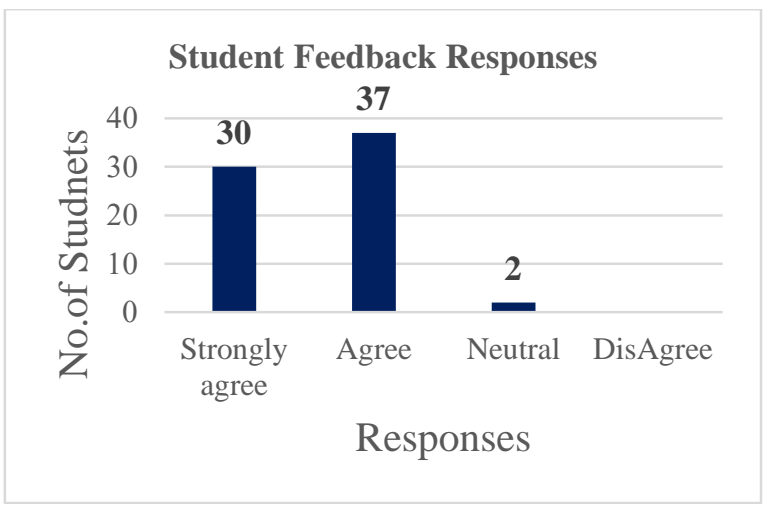

Figure 7: Students feedback responses on PBL

\section{The list of student project is as follows:}

1. Fault detection of induction motor over current using hall effect sensor

2. Fault detection of induction motor over voltage using hall effect sensor

3. New line following Robot using IR sensor

4. Coin based mobile charging system using solar panel

5. DC motor speed measurement using IR sensor

6. Distance measurement using ultrasonic sensor.

7. Temperature measurement using LM35 sensor.

8. Measurement of Humidity using the DHT11 sensor.

9. Flow measurement using YF-S201 Water flow sensor.

10. Soil test measurement for irrigation system.

11. Gas detection measurement using smoke sensor.

These are the lists of students' projects under course miniproject and students completed the tasks enthusiastically and worked in groups, teams. Feedback from students ensured that, they enjoyed this activity-based evaluation and useful learning occurred among themselves.

\section{Conclusions:}

This proposed PBL based activity for course delivery and assessment for instrumentation techniques EE3061 contributed to improve student's learnings and is mentioned through improvement $\mathrm{CO}$ attainment. As Cos are contribution to POs of the program it will also contribute improvement in POs. It is observed that the results of improvement in COs attainment is in the range of $70 \%$ to $77 \%$ and the POs attainment are in the range of $70 \%$ to $75 \%$. Also it is observed that students are actively participated with more interest towards the real time projects in groups. From this work student's skill set can be improved by involving in industry based real time course mini projects. Groups can be formed with a combination of slow learners and fast learners with appropriate assessment mechanism.

\section{Acknowledgement:}

We wish to acknowledge our indebtedness to Dr. Mrs. Sushma S. Kulkarni, Director, RIT, who encourages and support all faculty to implement activity-based teaching learning process, all Deans, HoD and faculties of Electrical Engineering Department, RIT for their continues support.

\section{References}

[1] Javier Macias- Guarasa, Member, IEE, Juan Maneul Montero, Member, IEEE, Ruben San-Segundo, Alvaro Araujo, and Octavio- Taladriz "A ProjectBased Learning Approch to Design Electronic System Curricula," IEEE TRANSACTIONS ON EDUCATION, VOL. 49, NO. 3, AUGUST 2006.

[2] VRSV Bharath P, R. A. Metri, D. Rajesh, I. Srikanth, C.L.Bhattar, "Implementation of Course-Mini Project (CMP) in Core Laboratory Course for the Attainment of Program Outcomes in Outcome Based Education," Journal of Engineering Education on Transformation (JEET), vol. 30, no.3, Issue 3, pp. January 2017.

[3] Mukund V. Kavade, "Assessment and attainment of Course Outcomes and Program Outcomes," Journal of Engineering Education on Transformations (JEET), Vol.28, No.2-3, Pg.77-84, 2015.

[4] Rajanikant A. Metri, V.R.S.V. Bharath Pulavarthi, I. Srikanth, C. L. Bhattar, "Microcontroller Laboratory Practices through Project-Based Learning," Journal of Engineering Education on Transformation (JEET), vol. 31, Issue 3, pp. 169-178, January 2018. 